this be used? As Dr King himself obliquely points out, their use to promote pseudo-religious fervour is unlikely to be helpful by itself, though it may be a necessary stage in providing the motivation needed to employ the ideas at all.

The main objection to rejecting scientific methods seems to lie in the fact that science is the only system known to promote the continuous development of understanding of the real world, however hesitant and gradual such progress may be. Systems dealing with entirely abstract matters (e.g. mathematics or legal coda) have shown progress similar to that of the sciences, but mind is not an abstraction analagous to mathematics as all of us know from our every-day experience. Psychoanalysis is more like an art, and arts, of course, flourish and fail as fashions change or schools of creative people assemble and disperse. Thus it seems likely that, without a scientific component, psychoanalysis would be as elegant and as useless to patients or the advancement of knowledge as a Byzantine mosaic.

It is untrue to claim that science cannot be applied to the study of mental phenomena simply because we do not know what these phenomena really are. Physicists do not know what electrons really are, but this has not prevented the growth of their understanding. Two scientific approaches to psychoanalysis are possible and have been tried. The first is to measure the consequences of applying psychoanalytic treatment to patients. The second is to use it to generate refutable hypotheses. In so far as the first approach has been adequately tried, results have suggested that psychoanalysis does not produce better results than treatment based on other systems of thought; indeed, cognitive therapy may often be more effective. The second approach is more difficult since psychoanalysis is so extremely diffuse, but most individual predictions that have been derived from it have either not been fulfilled or have been equally well explained on other bases. Although the matter has not been fully resolved, it looks as though psychoanalysis, however enticing it may appear, is neither particularly true nor particularly useful. One might wish to keep it in the same spirit as one might wish to keep a medieval bestiary, but it seems perverse to look for reasons to treat it as analogous to a valid textbook on zoology.

Dr King suggests that a main reason for thinking it useful is that psychoanalysis helps the advancement of knowledge because 'it emphasizes the full personal involvement of the mind of the investigator'. Yet scientists frequently write about the relationship between the personality of colleagues and their ideas (see Freeman Dyson's autobiography, some of C. P. Snow's books or many of the writings on Newton), while it is a fundamental principle of physics that you cannot measure anything without affecting it. It is doubtful that scientists need help to become aware of relationships between themselves and their work. Even if they do, it would be better if the awareness were aided by a demonstrably true theory.

There is after all, so much that needs to be done. We are only taking the first steps towards the adequate study of mind, so it is not surprising that we do not yet know very much. When one wishes to map a new area of knowledge, proper survey instruments are necessary in addition to one's own eyes and mind, and these are only at the earliest stages of development in our discipline. Yet they exist. For example, the combination of monoamine theory and biochemical assays has advanced knowledge of depression to a minor but real extent. Neuro-anatomy and nuclear magnetic resonance (NMR) or the newer EEG techniques may prove useful in understanding the psychoses. In psychotherapy, perhaps cognitive psychology and computerized repertory grid analysis might be a useful combination. With so many new fields to conquer, why waste time on nostalgia?

Royal South Hants Hospital

C. M. H. NUNN Southampton

\section{Expatriate stress and breakdown}

\section{DeAr SIRS}

As a British psychiatrist now living in the United States, I was particularly interested in the article by Drs Lipsedge and 'Caplan on 'Expatriate Stress and Breakdown' (Bulletin, May $1984,8,86-87$ ). Since I have certainly experienced the stress, although fortunately so far avoided the breakdown, I have a number of comments to make.

Firstly, 1 think it matters how long the expatriate remains overseas. As the US Internal Revenue Service quaintly phrased it when determining what taxes I should pay, there is a difference between being a 'resident' and a 'sojourner'. A sojourner is someone who is temporarily living in a foreign country but who regards their home as in their country of origin. Having lived in a number of different countries for short periods, I think that sojourning is much less stressful than becoming a resident, as one does not have to come to grips with many of the differences between Britain and the host country. However, I think that this is only possible for stays of perhaps up to one year; anything longer than that requires the person to adapt to the new culture.

Dr Caplan's suggestion of determining the person's previous coping abilities before sending them abroad sounds sensible but the problem is that I do not know of any life experience comparable to emigrating. The closest, in my opinion, was going away to university and even then I was still in my own country surrounded by many people in a similar situation. On the other hand, I would consider it most unwise to send abroad someone who has a history of psychiatric illness. There is no doubt that becoming an expatriate is stressful and that psychiatric disorders may recur under stress.

Ms Harris' comments on the vulnerability of women are interesting. I recently did a literature review on the psychological aspects of emigrating, and to my chagrin I found that expatriate women do less well psychologically than the men. My favourite explanation for this finding is that these studies were done in the days when the husband determined where a couple should live and his wife was expected to accompany him, regardless of her own feelings in the matter. However, I should also acknowledge that perhaps women are more 
emotionally tied to their family and country of origin and therefore more vulnerable to depression when separated from them. I could find no evidence as to whether or not married couples adjusted better than single persons, but it does seem clear that support from expatriates already living in the new country facilitates adaptation.

Finally, it is not only the children of expatriates who suffer from frequent moves, but also children whose parents relocate frequently within the home country. This is a problem in the USA where families are very mobile and increasingly executives are refusing to be transferred in the interest of providing a stable environment for their children.
However, a year or two spent living abroad can also be a positive experience for many families, especially when the children are young. I know several families who have done this and who look back on their experiences as valuable ones that have contributed to their understanding of both themselves and others. They often retain close ties with friends made in the host country and return there for holidays, showing that being an expatriate can be a positive as well as a negative experience.

Patricia B. R. Kolman

Langley Porter Pyschiatric Institute

San Francisco

\section{Reviews}

Hospitals in Trouble by J. P. Martin. Oxford: Basil Blackwell. 1984. Pp 273. £17.50.

The firm conclusion from this book is that the mental hospital inquiries of the last fifteen years have had very beneficial effects. Despite the great costs and the anguish that their procecdings have caused, in explaining failures they have taught many lessons in management which are being acted upon. They broke the log-jams of outdated practices and generated the will to change. The incidents of neglect or cruelty almost always occurred because management had allowed unsuitable persons to do the wrong tasks with inadequate training and leadership. A few years ago I searched in vain for a textbook for an MRCPsych course on administrative psychiatry. This could be it.

A synopsis of the 'old order' inquiries of the early 1970 s shows time and again how professional isolation results in poor standards of care. New recruits who wonder why staff rotate so much in mental hospitals and why their seniors go on so many courses will find the reasons here. And this recent history will show trainees how important they can be to the health of an institution because so often it was a newcomer who was the 'whistle-blower' on bad conditions and practices. Just when complacency assumes that these old order problems are gone. another incident occurs in some forgotten pocket of the service, sometimes in close proximity to progressive clinical units of the highest standard.

Then are described the troubles of changing services where innovation has begot staff conflict or too rapid development has produced disorganization and inadequate care, leading, for instance, to a spate of suicides. Anyone defending the notion of clinical autonomy of consultants must take account of some totally unacceptable consequences that are described here. Examples of failure of leadership are used to good effect to consider how a consultant or a manager should have acted in situations of great difficulty. Opportunities often existed for using expressed dissatisfactions to formulate new treatment policies. But it is necessary to understand those very human reasons why criticism was stified for so long that eventually it erupted in a public scandal.

A good deal of attention is given to the group processes which prevented staff reacting positively to criticism and allowed them to put loyalty to colleagues before patient welfare. A striking feature of more recent hospital inquiries is the prominence of strong professional groups and unions. Two unhappy consequences are discussed: the increasing legal complexity of investigations which get longer and more costly: the fear that complainants and witnesses will suffer more, as indeed some have, quite grievously, from ostracism and worse. Even the great improvements in complaints procedures which have taken place have not provided insulation against the wrath of colleagues.

Professor Martin has done a great job in collecting together all this original material because I personally found it difficult to obtain some of the inquiry reports, never mind find relevant press comment. If $I$ have one criticism, therefore, it is that he has sometimes abbreviated too much the description of persons, places and incidents so that the reader may be distanced from such things as part of another world. And yet there are still today wards and hospitals where there have been as yet no incidents but, to use his words: 'many staff doing their inadequate best in discouraging circumstances'. When one reads his description of the rationalizations that staff used to justify poor standards of care, I shudder a little to think how recently I have heard such remarks as: 'It is because we have no resources': 'They are too senile to notice anyway'; 'I treat them just like my own children'. Can that include an occasional clip around the car?

The second half of the book is entitled 'Remedies'. There is a lot of information about recent mental health policy, the Health Advisory Service and the National Health Service Commissioner, all of which have been greatly influenced by mental hospital inquiries in England and Wales. A fondly held idea that Scottish mental hospitals were somehow above these things is shattered by the case Professor Martin makes that it is merely that the Scotish Mental Welfare Commission carries out its 